\title{
Financial Literacy of Undergraduate Students: Do Personality Traits and Cognitive Ability Matter?
}

\author{
Akua Peprah-Yeboah (Corresponding author) \\ Assistant Lecturer, Department of Accounting and Finance \\ Kwame Nkrumah University of Science and Technology, Kumasi, Ghana \\ E-mail: apeprahyeboah@gmail.com \\ Weliko Emmanuel Blialy Frejus \\ Department of Accounting and Finance \\ Kwame Nkrumah University of Science and Technology, Kumasi, Ghana \\ Ernest Fianko \\ Department of Accounting and Finance \\ Kwame Nkrumah University of Science and Technology, Kumasi, Ghana
}

Received: December 7, 2018 Accepted: December 27, 2018 Published: December 31, 2018

doi:10.5296/ijafr.v8i4.14012

URL: https://doi.org/10.5296/ijafr.v8i4.14012

\begin{abstract}
This study investigates how psychological traits affect financial literacy levels at the undergraduate level of education. Using a cross-sectional survey of 580 students, the study examines whether the level of openness, conscientiousness and cognitive ability of students affect how financially literate they are. The Pearson's Correlation Test and Ordinary Least Square Regression methods are employed to test hypothesized relationships. The results show a generally low level of financial literacy. Further, openness, conscientiousness, and cognitive ability were found to have a statistically significant correlation with financial literacy ( $\mathrm{r}=0.349,0.287$ and 0.199 respectively). Similarly, the regression analysis found a positive relationship between all three variables and the dependent variable (financial literacy). Therefore, the study recommends that innovative financial literacy programmes that
\end{abstract}


target the youth need to be introduced. It is imperative that these programmes have components that are tailor-made for individuals with different personality traits to attract them. Finally, the programmes must contain aspects which aim to improve the cognitive abilities of the beneficiaries to increase their effectiveness.

Keywords: Cognitive ability, Conscientiousness, Financial literacy, Ghana, Openness

\section{Introduction}

Several antecedents and moderators of financial literacy have been probed over the past decade. Common among these factors are gender, age, educational background, length of time of holding a bank account, parental wealth, academic discipline, work experience, financial market involvement, income and money attitude (Cameron, Calderwood, Cox, Lim, \& Yamaoko, 2014; Albeerdy \& Gharleghi, 2015; Mireku, 2015). However, researchers are beginning to consider the possibility of a correlation between psychological and emotional predispositions, and financial literacy.

The connection between traits such as self-confidence, motivation, and willpower and an individuals' financial literacy have been explored (Benaboa \& Tirole, 2002; Arellano, Camara, \& Tuesta, 2014). The findings of such research show that respondents with positive personality traits such as self-confidence were likely to respond positively to financial education because of their perceived ability to excel at it. The role of self-confidence, which Patrick (2011) indicated as an aspect of agreeableness, can be a relevant factor affecting the way in which young people deal with financial issues (Benaboa \& Tirole, 2002). Generally, the results of such studies go to show that individuals exhibiting high levels of self-confidence and willpower recorded higher levels of rational financial behaviors than other respondents with less of these traits.

This study seeks to extend these arguments by exploring psychological predicators to financial literacy. Specifically, the effect of openness, conscientiousness and cognitive ability are examined. Open-mindedness and a willingness to learn cannot be dismissed as determinants of financial literacy, as personal attitudes appear to be an essential element in determining financial behavior (Johnson \& Staten, 2010; Borghans, Duckworth, Heckman, \& Ter Weel, 2008). Open minded individuals are more adventurous and risk-seeking, enabling them to be explorative in their learning. Such individuals demonstrate proactive learning behaviors and so are more likely to be curious. Therefore, they tend to look for and compare financial services (Arellano, Camara, \& Tuesta, 2014).

Another emerging perspective is the relationship between an individual's cognitive ability (cognition) and financial literacy (Banks \& Oldfield, 2007; Benjamin, Brown, \& Shapiro, 2006). Among the various cognitive skills, numeracy has been of utmost interest in previous studies since it is believed that an individual with high numeracy skill can usually make complex and optimal financial decisions in aspects including investment and savings (Peters, Västfjäll, Slovic, \& Mertz, 2006). Research suggests that individuals with high numeracy skills and abilities are more likely to retrieve and use appropriate numerical principles, thus 
making themselves less susceptible to framing effects (a cognitive bias where an individuals decision is influenced by how the problem is presented).

Further, this study focuses on the undergraduate level of education. Individuals at this level are at the cusps of adulthood and are faced with critical life choices, many of which are financial. In acknowledgment of this fact, there have been efforts made to understand financial literacy at this level from various perspectives. Studies show that financial literacy has immediate and future consequences for the student. Whiles in school, the financial decisions of students can result in financial distress which in turn results in poor academic performance (Bongini, Trivellato, \& Zenga, 2016). However, as Grable and Joo (1998) explain, if university students are financially literate, they make better decisions for themselves and so face fewer financial hardships. Ultimately, this results in economic development for the whole country.

Due to the potential benefit that financial literacy offers to the economy, (Mitchell \& Lusardi, 2015), it is a critical factor in the development efforts of emerging countries. As Gary, Sebstad, Cohen, \& Stack (2009) point out, the financial landscape of developing countries change rapidly. Thus their populations continuously live on the margin, making financial literacy skills imperative if they are to survive and thrive. However, efforts to understand financial literacy from the perspective of emerging markets have been modest at best (Refera, Dhaliwal, \& Kuar, 2016). To this end, this study is set in Ghana, a Sub-Sahara African country. The choice of Ghana is informed by the plethora of financial misappropriations that have colored its financial sector in the past few years. Huge financial scandals like the DKM Ponzi scheme which collapsed in 2016 and the more recent Menzgold saga call the financial knowledge of the patrons into question. However, little is known about the level of financial literacy in Ghana (Mireku, 2015). This study, therefore, explores the financial literacy level of undergraduate students in Ghana and examines whether psychological traits play a role in determining how financially literate they are.

The rest of the study is structured into a review of existing literature and development of a conceptual framework, a presentation of the methodology used, findings and discussion and finally a conclusion.

\section{Literature Review}

\subsection{Definition of Financial Literacy}

Most studies on financial literacy tend to agree that it is difficult to define the concept (Mbekomize \& Mapharing, 2015). The term 'financial literacy' was unknown until the Jumpstart Coalition for Personal Financial Literacy defined it (Sarigül, 2014) as the ability to use knowledge and skills to manage financial resources securely and effectively throughout one's lifetime (Hastings, Madrian, \& Skimmyhorn, 2012). In the view of Lusardi and Mitchell (2013), financial literacy is the ability to process financial/economic information and make informed decisions about financial planning, wealth accumulation, pension, and debt. According to Atkinson and Messy (2012) financial literacy is the combination of awareness, knowledge, skill, attitude, and behavior essential to make sound financial decisions and to 
achieve individual well-being. Mason and Wilson (2000) further defined financial literacy as an individual's ability to obtain, understand, and evaluate the relevant information necessary to make decisions with an awareness of the likely financial consequences.

Critically evaluating the above definitions reveals that financial literacy is not just about having an idea of some financial management concepts, but instead the ability to understand the relevance and use of such financial management concepts in making informed financial decisions and also evaluating the impact of these financial decisions on the material well-being of the individual. In this respect, financial literacy, for this study, is defined as having knowledge and understanding of financial and economic concepts (including, inflation; risk diversification; interest; investments; money management; savings; and dividend). Also, applying it to making informed financial decisions, taking into consideration the consequences of such decisions with the objective of improving the financial and socio-economic well-being of the individual.

\subsection{Importance of Financial Literacy}

According to Capuano and Ramsey (2011) individuals, economic systems and the community all benefit from financial literacy. As the financial literacy of an individual improves, their ability to make sound financial and economic decisions also improve. Their savings, borrowing, and investment habits are enhanced thereby increasing how efficiently they manage money. According to Engelbrecht (2011), the inability of many poverty reduction efforts to succeed in developing countries can be traced to the low levels of financial literacy of the target population for such interventions. The deficiency in financial knowledge restricts their ability to take advantage of the opportunities that these interventions offer them. As Refera, Dhaliwal and Kuar (2016, p. 5) express, an investment in the financial literacy of a country's inhabitance "improves personal financial management, which in turn, will be manifested through better financial behavior and financial outcomes."

Furthermore, existing literature shows that financial literacy does not only affect the financial well-being of individuals but has a more holistic impact. The individuals' self-confidence, control, and independence are shown to be promoted by financial literacy since control over one's finances translates into a feeling of having control over one's life (Allen, Edwards, Hayhoe, \& Leach, 2007). Again, Norvilitis, Szablicki, and Wilson, (2003) added that perceived financial well-being among college students are associated with psychological well-being, a feeling of being in control of their lives and exhibition of lower levels of dysfunctional attitudes. Further, research has revealed that financial literacy is not only beneficial to an individual but families as well (Blalock, Tiller, \& Monroe, 2004). Financial literacy and behaviors are also deemed to be important in marriage since good financial behavior such as budgeting, paying debt and spending within budget all increase marital satisfaction (Kerkmann, Lee, Lown, \& Allgood, 2000).

Additionally, increasing financial literacy levels result in improved financial inclusion. Financially literate individuals are more likely to seek and receive financial services and products in their quest to manage their finances (Nalini, 2011). This has a positive impact on the financial stability of the economy. Further, finance savvy clients demand quality financial 
services from financial institutions thus compelling them to be innovative and efficient in operations, thus encouraging the growth and development of the sector (Shankari, Navarathinam, \& Suganya, 2014). They are also less likely to need help understanding basic features of different financial products thus financial service providers save time and money in customer care costs (Mundy \& Masok, 2011)

In summary, the benefits of financial literacy are numerous and impact on an individual, the community and the country as a whole.

\subsection{Factors Influencing Financial Literacy}

Several studies have tested the significance of variables such as gender, educational background, academic discipline, age, family, work experience, parent's educational background, etc. on the level of financial literacy, and have found relationships between these factors and financial literacy to varying degrees.

With regards to the educational background, for instance, business students (and those with economics background) were mostly found to be more financially literate than non-business students (Mireku, 2015; Mbekomize \& Mapharing, 2015; Shaari, Hasan, Ramesh Kumar Moona Haji, \& Mior Ahmad Jafri Md, 2013). Further, accounting students were more financially literate than non-accounting students (Mireku, 2015; Oppong-boakye \& Kansanba, 2013). In contradiction to these findings, however, Mandell (2008b) found no significant relationship between educational background and financial literacy.

Another area of inquiry has been the role of the academic level of a student in how financially literate he or she is. Mireku (2015) and Oppong- Boakye, and Kansanba (2013) found that the longer students have been in school, the more financially literate they are. That is, third year and fourth-year students knew more about financial management than first year and second-year students. Here too, Ansong and Gyensare (2012) found contradicting results that showed no statistically significant relationship between the level of study and financial literacy. Work experience of students has also been proven to have a statistically significant positive association with financial literacy (Ansong \& Gyensare, 2012; Mireku, 2015). Therefore, students with a long period of work experience are financially literate than those with low and none work experience

Another area of interest for researches of financial literacy is what has come to be known as the "gender gap" in financial literacy. The gender gap refers to the fact that men are found to be more financially literate than women (see Lusardi and Mitchell, 2014) therefore indicating that gender determines financial literacy. This gender difference appears to be the case across different age groups (Chen \& Volpe, Gender differences in personal financial literacy among college students, 2002; Mandell, Financial literacy of high school students, 2008), irrespective of the complexity of the test questions administered (Lusardi, Mitchell, \& Curto, 2010; Hung, Andrew, \& Yoong, 2009; Fonseca, Mullen, Zamarro, \& Zissimopoulos, 2012). This phenomenon has been attributed to various factors such as the thinking that someone else (thus, a husband) would take care of their finances on their behalf. 


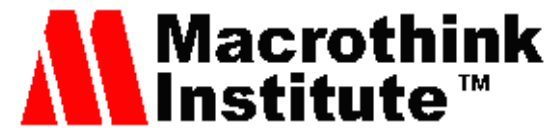

International Journal of Accounting and Financial Reporting

ISSN 2162-3082

2018, Vol. 8, No. 4

Shaari et al. (2013) also found that age and gender are negatively associated with financial literacy. That is, financial literacy levels were higher among the younger age brackets than the older groups. The position of these authors concerning the relationship between age and financial literacy is inconsistent with the findings of previous studies (Akben-Selcuk \& Altiok-Yilmaz, 2014; Ansong \& Gyensare, 2012; Lusardi \& Mitchell, The economic importance of financial literacy: theory and evidence, 2014). Lusardi and Mitchell (2014) indicated that females tend to be financially literate as they approach widowhood since they no longer expect there to be someone (husband) to cater for their finances. Hence the research on financial matters concerning savings and investment. In contrast, Arceo-Gómez and Villagómez (2017) found no significant gender difference as far as financial literacy is concerned and argued that gender, to a greater extent, is no predictor of financial literacy. An emerging perspective in financial literacy research is the role of psychological factors in the attainment of financial knowledge. The next section discusses these perspectives.

\subsubsection{Personality Traits}

Personality traits are the attributes, long-lasting pattern of thoughts, emotions and, behavior that are stable over time and explain people's behavior across different situations and circumstances (Costa, Terracciano, \& McCrae, 2001). An individual's personality trait can best be described using the Five-Factor Model (FFM) which has received widespread acceptance and its existence generally proven by past and recent researchers (Caspi \& Moffitt, 2006; Barnett, 2015). According to this model, an individual's personality can be defined under:

Neuroticism: the emotional stability of the individual and all aspects of anxiety, hostility, depression, self-awareness, impulsivity, and emotional vulnerability. According to Emmons, Diener, and Larsen (1985), neurotic individuals experience more negative life events because of their tendency to put themselves into situations that foster adverse effects.

Extraversion: the individual's degree of interpersonal skills, friendliness, warmth, assertiveness, activist, thrill-seeking, and positive emotions. Watson and Clark (1997) indicated that persons with high scores in this type of trait, are characterized as more energetic, optimistic, and tends to show higher levels of commitment to social groups and activities.

Openness to experience (Openness): generally denotes how open-minded a person is. McCrae (1996) describes that such individuals show interest in new experiences or new ideas in various fields such as fantasy, aesthetics, emotions, actions, and values. That is, individuals with high levels of such traits are deemed as imaginative, curious, and creative. In this respect, individuals with a low score in this dimension tend to prefer the familiar and the old experiences instead of new ideas.

Agreeableness: the way in which the individual interacts with his/her environment regarding trust, direct approach, altruism, responsiveness to the needs of the environment, humility, and tenderness. Common characteristics among people with a high level of agreeableness are 


\section{Mll Macrothink}

International Journal of Accounting and Financial Reporting

ISSN 2162-3082

2018, Vol. 8, No. 4

confidence, sympathy, willingness to help, and the ability to express mercy and compassion (Patrick, 2011).

Conscientiousness: the ability to control impulses, to avoid impulsive behavior, and demonstrate disciplined output of defined motives. Conscientious persons tend to maintain order, comply with obligations, reach achievements, be ambitious, have self-discipline, and be prudent in their behavior. They are organized, punctual, reliable, trustworthy, and set targets and goals for themselves (Patrick, 2011).

This study limits its scope to conscientiousness and openness as they could easily be linked to variations in learning outcomes (i.e., financial literacy).

\subsubsection{Cognitive Ability}

The cognitive ability of an individual describes the general ability factor (Palumbo, 2008) which determines common variances shared by tests of specific skills such as spatial ability, verbal ability and numerical ability (Hough \& Oswald, 2000). An individual's cognitive ability can also be defined as his or her intelligence as measured by IQ tests and cognitive intelligence test (CAT). Since intelligence and cognitive ability share the quality of being stable over time, cognitive ability and intelligence are deemed synonymous (Palumbo, 2008).

For this study, arithmetical (numeracy) aspects of students' cognitive abilities will be tested to see the extent to which it affects the link between gender and financial literacy. This aspect of cognitive ability is deemed necessary in financial literacy as most financial matters such as risk diversification, inflation, compound interest, etc. involve the use of mathematical operations to arrive at conclusions.

\subsection{Conceptual Framework}

This study posits that psychological factors contribute to determining the financial literacy of undergraduate university students. Specifically, the personality traits of openness and conscientiousness, as well as cognitive arithmetic ability, are probed.

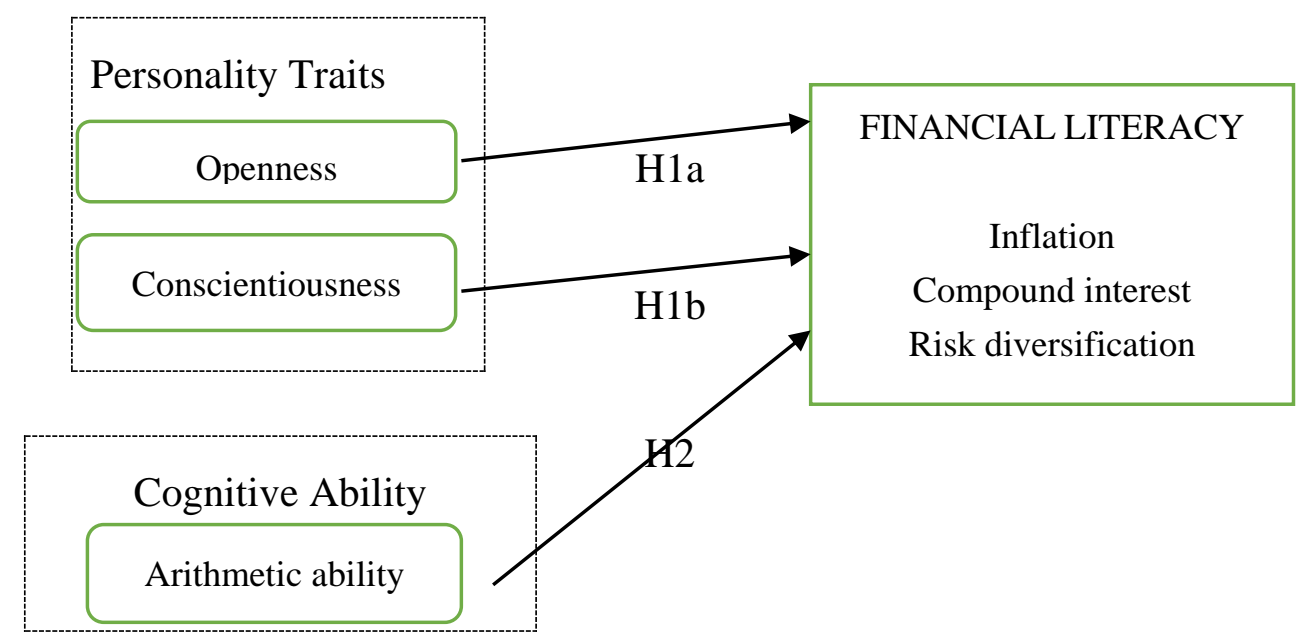

Figure 1. Conceptual framework 
It is expected that the more open students are, the more likely it is that they will demonstrate proactive learning behaviors (Arellano et al., 2014) which will result in higher financial literacy. Also, it is expected that conscientious students will tend to be financially literature due to their affinity for maintaining order, complying with obligations, reaching achievements, being ambitious, having self-discipline, and being prudent in their behavior (Patrick, 2011). In line with these arguments, the study hypothesizes that:

H1a: Openness has a statistically significant positive effect on financial literacy

H1b: Conscientiousness has a statistically significant positive impact on financial literacy

Additionally, it is anticipated that individuals with high arithmetic ability who can draw stronger inferences and precise meanings from numbers and numerical comparisons will have higher levels of financial literacy than individuals with low numeracy. Individuals who are deficient in arithmetic ability are influenced more by competing, irrelevant affective considerations, therefore impeding their ability to making sound financial decisions (Peters, Västfjäll, Slovic, \& Mertz, 2006). Per these insights, it is posited that:

$\mathrm{H} 2$ : Arithmetic cognitive ability has a statistically significant positive effect on financial literacy

\section{Method}

A cross-sectional survey design was employed for this study, following previous studies (Mireku, 2015). The study is set in the Kwame Nkrumah University of Science and Technology, one of the most prominent universities in the West African sub-region, with the target population being the students in the second semester of the 2016/17 academic year. Given the large population sizes, the stratified sampling approach was used. A sample was selected from each of the six colleges of the institution. The convenience sampling method was used for the selection; students were handed questionnaires in lecture halls, libraries, and hostels.

In total, 710 questionnaires were distributed, informed by Hair et al. (2014) who suggest that for generalizability purposes and when performing multiple regression, a minimum sample size of 50 or 100 observations is ideal. Therefore a minimum of 100 students from each stratum or college was targeted, resulting in 710 students overall. Six hundred seventy-one questionnaires were returned, out of which 580 were found to be useable thus an effective response rate of $81.69 \%$ was achieved.

The survey instrument contained two main sections. The first section captured data on students demographics namely: gender, age, level, college, the source of income, level of income and academic performance. Most of the items in this section were captured from the questionnaires employed by prior researchers like Mireku (2015).

The second section was further grouped into three subsections. Firstly the respondents' financial literacy was measured by accessing their understanding of risk diversification, compounding interest and inflation. Lusardi and Mitchell's (2015) 'Big 3' financial literacy measures (inflation, compound interest, and risk diversification) were employed. This method 
of assessment was deemed appropriate as it offered simplicity, relevance, brevity as well as diversity (Lusardi and Mitchell, 2015). Three sub-questions were asked under each of the 'Big 3' measures. Thus, in all, nine (9) multiple-choice questions were used to assess the overall level of financial literacy of the respondents.

The second sub-section focused on the cognitive arithmetical ability of respondents. Three quiz-like questions were asked to assess their level of cognitive (arithmetical) ability. The s adopted from the cognitive reflection test developed and tested by Frederick (2005) because "it has been found to be a very efficient way to estimate the cognitive abilities of individuals in questionnaires"' (Bucher-Koenen and Ziegelmeyer, 2011 p. 17)

The third and final sub-section of the instrument assessed the respondent's openness and conscientiousness. Firstly, the openness of the respondents was tested in ten questions. Then another ten questions measured how conscientious respondents are. In both cases, these personality traits were self-reported on a 1 to 5 Likert scale ranging from 'not at all' to 'to a larger extent.'

Before the actual field study, a pre-test of the data collection instrument was executed to validate the instrument. After the necessary corrections and adjustments are made, the actual field study was carried in the second semester of the 2016/17 academic year. In line with the purpose of the study, a quantitative research strategy was deemed appropriate. Accordingly, various statistical techniques and procedures were considered relevant. Both descriptive and inferential analytical tools and processes were employed in analyzing data collected. Specifically, frequencies, percentages, means, and standard deviations were relied on to provide descriptive results. The hypotheses of the study were tested using the Ordinary Least Square regression method. The analysis was done using Statistical Package for Social Sciences (SPSS), IBM version 21. Each test item was coded and entered accordingly on the SPSS's pre-coded spreadsheet. After this procedure, the data was then analyzed based on the specific objectives of the study.

\section{Results and Discussion}

\subsection{Demographics of Respondents}

$51.2 \%$ (297) and $48.8 \%$ (283) of the data collected for the study were provided by male and female students respectively. Therefore, gender parity was achieved in the study. Further $3.4 \%$ (20), 66.9\% (388), 28.5\% (165) and 1.2\% (7) of the respondents fell between the ages of ' 18 or below', '18 and 22', '23 and 27', and '28 or above' years respectively. This distribution generally characterizes undergraduate students in the country, where the majority are between 18 and below 23 years. Regarding students' academic level, the majority of the respondents are in their final year $(29.8 \%, 173)$. There was an even distribution of the respondents in respect of the other levels. Thus, 22.1\% (128), 25.9\% (150) and 22.2\% (129) of the respondents were in the first, second and third year respectively. Also, of the six colleges in KNUST, most respondents were from the College of Humanities and Social Sciences $34.1 \%$, 198) whereas least of the respondents were from the College of Art and Built Environment $(12.4 \%, 72)$. In all, there was an even distribution of the respondents among the remaining 


\section{Mll Macrothink}

International Journal of Accounting and Financial Reporting

ISSN 2162-3082

2018, Vol. 8, No. 4

Colleges as follows: Agriculture and Natural Resources, 12.6\% (73); Engineering, 13.8\% (80); Health Sciences, $13.6 \%$ (79) and Science $13.4 \%$ (78).

Most of the respondents $(76.2 \%, 442)$ rely entirely on their family for their finances on campus since they are studying full time and so are not working. However, 3.1\% (18) fully financed their education by themselves, $17.1 \%$ (99) were partly supported, and $3.6 \%$ (21) had finance from sponsorships and scholarships. In relation to the income level received by the respondents every semester, majority of them $(31.2 \%, 181)$ earn an income of 'GHS901 or above' per semester, with 29.3\% (170), 25.9\% (150) and $13.6 \%$ (79) receiving between 'GHS601 and GHS900', 'GHS301 and GHS600', and 'GHS300 or less' respectively.

Also, in relation to the educational background of the respondents' parents, fathers of respondents were found to be generally more educated than mothers with a majority of the men $(51.2 \%, 297)$ having some form of tertiary education, whiles majority of mothers $(40.2 \%$, 233) had a secondary educational background. In specific terms, $2.6 \%$ (15), 10.3\% (60) and $35.9 \%$ (208) of the respondents' fathers have no educational level, primary educational level and secondary educational level respectively, whereas, $4.7 \%$ (27), 24.3\% (141), and 30.9\% (179) of the respondents' mothers have no educational level, primary educational level, and tertiary educational level respectively. In all, only $24.3 \%$ (141) of the total respondents were business students with a majority $(18.3 \%, 26)$ specializing in Accounting. Four hundred and thirty-nine respondents (75.7) came from the other faculties of the university. Also, 12\% (17) of the business students has no explicit specializations for the time being, since they are in levels 100 and 200.

\subsection{The Financial Literacy Level of Respondents}

In the assessment of students' level of financial literacy, most authors (Chen \& Volpe, 1998; Mireku, 2015) adopted the approach of measuring this concept by using the overall number and/or percentage of correct answers provided by the respondents to the questions on each of the aspects of financial literacy applied in the study.

Table 1. Financial literacy grading of respondents

$$
\text { INFLATION }
$$

\begin{tabular}{llll}
\hline Grading System $(\%)$ & $\mathbf{n}$ & $\%$ & Grade \\
$<=39$ & 378 & 65.1 & $\mathrm{~F}$ \\
$60-69$ & 139 & 24 & $\mathrm{~B}$ \\
$70-100$ & 63 & 10.9 & A \\
\hline
\end{tabular}

\section{COMPOUND INTEREST}




\begin{tabular}{llll} 
Grading System (\%) & n & \% & Grade \\
$<=39$ & 448 & 77.3 & F \\
$60-69$ & 98 & 16.9 & B \\
$70-100$ & 34 & 5.9 & A \\
\hline RISK DIVERSIFICATION & n & $\%$ & Grade \\
\hline Grading System $(\%)$ & 442 & 76.3 & F \\
$<=39$ & 118 & 20.3 & B \\
$60-69$ & 20 & 3.4 & A \\
$70-100$ & & & \\
\hline
\end{tabular}

\section{OVERALL FINANCIAL LITERACY}

\begin{tabular}{llll}
\hline Grading System $(\%)$ & $\mathbf{n}$ & $\%$ & Grade \\
$<=39$ & 377 & 65.0 & $\mathrm{~F}$ \\
$40-49$ & 81 & 14.0 & $\mathrm{D}$ \\
$50-59$ & 49 & 8.4 & $\mathrm{C}$ \\
$60-69$ & 40 & 6.9 & $\mathrm{~B}$ \\
$70-100$ & 33 & 5.7 & $\mathrm{~A}$ \\
\hline
\end{tabular}

This study employs the approach of Mireku (2015) by using the grading system of KNUST (thus, 70\% and above: A - Excellent; 60-69\%: B - Very Good; 50-59\%: C - Good; 40-49\%: D - Satisfactory and below 40\%: F - Fail) as a benchmark for assessing the financial literacy of respondents. The comparative results of respondents in risk diversification, compound interest, and inflation, is shown in table 1 above. For each dimension of financial literacy measured, students had a shallow level of knowledge. However, the results show a relatively higher knowledge in inflation compared to compound interest and risk diversification. Whiles $34.9 \%$ of respondents achieved the pass mark of 40 and higher for inflation, only $22.8 \%$ and $23.7 \%$ 'passed' in compound interest and risk diversification respectively. Overall, only $35 \%$ of respondents achieved a score above $40 \%$ in total. 


\section{Ml Macrothink}

International Journal of Accounting and Financial Reporting

ISSN 2162-3082

2018, Vol. 8, No. 4

Further, the average score in inflation, compound interest, and risk diversification were $37.0 \%, 27.8 \%$, and $29.2 \%$ respectively. On average, only $31.3 \%$ of questions were answered correctly. These findings show a worse situation than that found by Mireku (2015) who recorded a literacy level of about $48.6 \%$.

\subsection{Personality Traits of Respondents}

Table 2. Openness and conscientiousness levels of respondents

\section{OPENNESS}

\section{MEASURES}

1. I am open to new experiences

2. I like patronizing goods when they first hit the market
3. I understand that things do not always go as expected

Min Max Mean SD

$\begin{array}{llll}1 & 5 & 3.26 & 1.078\end{array}$

$\begin{array}{llll}1 & 5 & 2.59 & 1.058\end{array}$

$1 \quad 5 \quad 3.49$

4. I feel it was not a waste of government funds to print the new 5 cedis bill

$\begin{array}{llll}1 & 5 & 2.95 & 1.161\end{array}$

5. I have a constant need to learn $1 \quad 5 \quad 3.42$

1.088

6. I like researching on financial issues

$\begin{array}{llll}1 & 5 & 2.88 & 1.066\end{array}$

7. I adapt easily to unforeseen situations

$\begin{array}{lll}1 & 5 & 3.09\end{array}$

1.004

8. I like investing in high risk/high return companies

$1 \quad 5 \quad 2.61$

1.156

9. I always have the impression that new things are for the best

$\begin{array}{llll}1 & 5 & 2.96 & 1.068\end{array}$

10. I easily adapt to a new environment

$1 \quad 5 \quad 3.32$

1.032

COMPOSITE SCORE (AVERAGE)

$1 \quad 5 \quad 3.06$

.0653

\section{CONSCIENTIOUSNESS}

MEASURES

1. I normally prepare and adhere to my spending budgets
Min

Max Mean

SD

$\begin{array}{llll}1 & 5 & 3.07 & 1.064\end{array}$ 
2. Every item in my room and on my desk has its designated place

3. I often think of potential consequences before rushing into actions

$\begin{array}{llll}1 & 5 & 3.55 & .993\end{array}$

4. In my opinion, all laws should be strictly enforced

5. I have a fixed percentage of my income going into savings 1

6. I create a shopping list before I go shopping

8. I always do what is expected of me, thus, nothing more or nothing less

9. I become annoyed when things around me are disorganized

Note: SCALE: $1=$ not at all; 2=somehow; 3=some extent; 4= large extent; 5=larger extent

Table 2, shows that, on average, the respondents are open to some extent (mean=0.306; $\mathrm{SD}=0.0653$ ). This overall inference is true for each specific item tested under openness, and this is evidenced from the fact that the overall standard deviation is small and the means of each specific item is very close to the composite mean score. For instance, the respondents are, to some extent open to new experiences, given a mean score of 3.26 (approximated as 3).

The self-reported results show that respondents believe they are to some extent conscientious (mean=3.25; $\mathrm{SD}=0.640$ ). However, this inference is also valid for each of the items tested to assess the respondent's conscientiousness level. For instance, on average, the students normally prepare and adhere, to some extent, to their spending budgets (given that, mean=3.07; $\mathrm{SD}=1.064)$. 
4.4 Cognitive Arithmetic Ability of Respondents

Table 3. Cognitive (arithmetic) ability of respondents

\begin{tabular}{lll}
\hline MEASURES & $n$ & $\%$ \\
& correct & correct \\
\hline
\end{tabular}

1. A bat and a ball cost 110 cedis in total. The bat costs 100 cedis more than the ball. How much does the ball cost?

3. In a lake, there is a patch of lily pads. Every day, the patch doubles in size. If it takes 48 days for the patch to cover the entire lake, how long would it take for the patch to cover half of the lake?

This study further investigates, implicitly, the link between students' arithmetical ability and their level of financial literacy. As table 3 shows, on average, the arithmetical abilities of the respondents (i.e., students) are weak or very low, given an overall average correct score of $18.17 \%$. Thus, on average, only $18.7 \%$ of the respondents provided correct responses to the test questions assessing students' cognition.

Appendix 1 provides evidence of a statistically significant relationship between openness and financial literacy. Therefore, the correlational results point to the fact that, there is a moderate positive relationship between openness and financial literacy (i.e., $=0.349$ ). Students with highly creative and initiative skills who are not conservative and are for that matter open to new experiences have a relatively higher level of financial literacy than their counterparts with lower levels of openness. This positive relationship is statistically significant at an alpha level of 0.05. Therefore this finding is consistent with the study's hypothesis (H1a) that openness is positively related to the financial literacy of tertiary students.

Further, Appendix 1 shows a moderate positive relationship between students' level of conscientiousness and their level of financial literacy (i.e., $r=0.287$ ). Thus, students who are more conscientious are more financially knowledgeable than students who are less conscientious. Additionally, this positive relationship is statistically significant at an alpha level of 0.05 . This finding is, therefore, confirms the study's hypothesis (H1b) that conscientiousness positively affects financial literacy among tertiary school students.

Regarding the relationship between students cognitive abilities and financial literacy, appendix 1indicates a weak positive relationship between cognitive abilities and financial literacy (i.e., $r=0.199$ ). This positive relationship is statistically significant at an alpha level of 


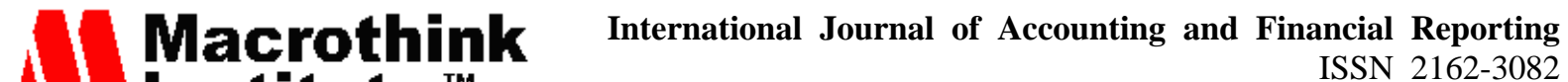 Institute $^{\mathrm{TM}}$

0.01. This finding is, again, consistent with the study's hypothesis (H2) that arithmetic cognitive ability positively affects financial literacy.

\subsection{Regression Analysis and Model Specification}

Table 4. OLS Regression analysis results

VARIABLE

Dependent: Financial literacy

VIF

Control paths

Age

$-.022(-.560)$

.791

Level

$.180(4.494)^{* * *}$

Income (maintenance)

$-.018(-.489)$

Academic perf. (CWA)

$.179(4.934)^{* * *}$

Programme (business)

$.127(3.224)^{* * *}$

.778

Previous school type

$.025(.704)$

.914

Religious affiliation

$.012(.324)$

Ethnic background

$.026(.702)$

.868

Father's education

$.009(.218)$

.678

Mother's education

$-.103(-2.435)^{*}$

.674

Sex

$.201(5.376)^{* * *}$

Hypothesized paths:

Main effects:

Openness

$.169(4.052)^{* * *}$

Conscientiousness

$.191(4.878)^{\text {*** }}$

Cognition (arithmetic)

$.092(2.527)^{*}$

.908

R-square 


\section{Il Macrothink}

$\Delta$ R-square

$\Delta$ F-statistics

Degree of freedom

Notes: $\mathrm{t}$-values are in the parenthesis; ${ }^{*} \mathrm{p}<.05$ (2-tailed); ${ }^{* *} \mathrm{p}<.01$ (2-tailed)

To assess the extent to which personality traits (openness and conscientiousness) and cognitive (arithmetic) abilities affect financial literacy an Ordinary Least Square regression was performed using the following model:

$$
\begin{aligned}
& \mathrm{FL}=\beta_{0}+\beta_{1} \mathrm{~A}+\beta_{2} \mathrm{~L}+\beta_{3} \mathrm{I}+\beta_{4} \mathrm{AP}+\beta_{5} \mathrm{PS}+\beta_{6} \mathrm{RA}+\beta_{7} \mathrm{~EB}+\beta_{8} \mathrm{FE} \\
& +\beta_{9} \mathrm{ME}+\beta_{10} \mathrm{G}+\beta_{11} \mathrm{O}+\beta_{12} \mathrm{C}+\beta_{13} \mathrm{CA}+\varepsilon
\end{aligned}
$$

Where:

1. Dependent variable: $\mathrm{FL}=$ financial literacy

2. Independent variables: $\mathrm{A}=$ Age, $\mathrm{L}=$ Level, $\mathrm{I}=$ Income, $\mathrm{AP}=$ Academic performance, $\mathrm{PS}=$ pervious school type, $\mathrm{RA}=$ religious affiliation, $\mathrm{EB}=$ ethnic background, $\mathrm{FE}=$ father's education, $\mathrm{ME}=$ mother's education, $\mathrm{G}=$ gender, $\mathrm{O}=$ openness, $\mathrm{C}=$ conscientiousness, $\mathrm{CA}=$ cognitive (arithmetic) ability,

3. $\beta_{0,} \beta_{1-13,} \varepsilon$ are the intercept, regression coefficients, and error terms respectively

The regression analysis further confirmed the correlation results. Openness, Conscientiousness, and Cognition have a statistically significant positive effect on financial literacy. As shown in Table 4, each of these variables has a significant impact on financial literacy, which offers sufficient support to the assertion of the effects of conscientiousness, cognitive ability, and openness on financial literacy.

\subsection{Discussion}

The study sought to assess the level of financial literacy of undergraduate students. Findings from this study posit that students know issues concerning inflation better than compound interest and risk diversification. Overall, results showed a low level of financial literacy among tertiary students. This finding of low financial literacy is consistent with the findings of previous studies (e.g., Arceo-Gómez and Villagómez, 2017; Mireku, 2015; Chen and Volpe, 1998; Cameron et al., 2014), although the extent of deficiency varies. For instance, whereas Mireku found $48.6 \%$ of the respondents were financially literate, this study found only $35 \%$ being financially literate. This variation may be because the different studies adopted different dimensions to measuring financial literacy. However, this brings to bear the fact that respondents may only be knowledgeable about certain aspects of finance and not others. 
A possible reason for this low level of financial literacy is that students are not well exposed to financial issues and basic finance concepts. Most students, arguably, focus on their core programme and do not make efforts to explore financial matters. Further, the age distribution of the respondents indicates that most of the respondents (thus, 70.3\%) are below age 23 . Therefore, majority of the students are in their early financial life cycle, where students depend primarily on their parents and guardians, and as such have little incentive to save. Additionally, the correlational results show a statistically insignificant positive relationship between income and financial literacy, arguably because the income students' receive from the parent's only support spending, with little surplus cash left for savings.

As expected, personality traits were found to have a positive relationship with financial literacy. This finding is in line with the thinking that people who are open-minded are more likely to gain financial literacy because they are curious, adventurous and willing to explore new knowledge, and conscientious individuals will possess the self-discipline to research and gain the insight. The regression analysis points to the fact that business students are more financially literate than other respondents, probably because they are exposed to financial information as part of their programme of study. However, with over $76 \%$ of respondents not studying business and also relying fully on their family for sustenance, there is little incentive to take on the added task of financial literacy. Therefore, students will need to take the personal initiative to gain financial knowledge, thereby making their personality a critical factor in determining their level of financial literacy.

Again cognition was found to have an impact on financial literacy; it is interesting to note the low levels of arithmetic ability at that level of education especially in a Science and Technology focused university. This finding begs for more study. The correlation results show a positive relationship between cognition and academic performance; therefore students with higher academic achievement have higher cognitive ability and higher financial literacy. The study reveals that the intelligent students will have higher numeracy skills and this will help them in acquiring and understanding financial knowledge.

\section{Conclusion}

This study tested respondents' ability to identify and respond to issues of inflation, compound interest, and risk diversification. An assessment of their responses showed that generally, financial literacy among the tertiary students surveyed in KNUST was relatively low. This finding accentuates the findings of prior authors (see Chen and Volpe, 1998; Lusardi and Mitchell, 2014; Cameron et al., 2014; Mireku, 2015). Further, personality traits and cognitive ability are essential factors in determining the level of financial literacy.

The findings indicate a persisting deficit of financial knowledge among youths even in the tertiary institutions. Therefore, less learned people are likely to have much less aptitude on financial issues. Financial literacy programmes need to be made more accessible to university students and the general public because of their overwhelming benefit to national development. However, the personality traits of the target population need to be factored into the programmes' design and advertisement to make it attractive and beneficial across the different personality traits. Also, such programmes should include components that are 
designed to improve the arithmetic ability of the target group as they are more likely to benefit from such programmes as their numeracy improves.

The current study is limited in its methodology and scope as it considered only undergraduate students in one university. Generalization in other settings should be done with caution. The findings of this novel study call for a deeper dive into how personality affects financial literacy. It is therefore recommended that further studies on how other psychological traits like agreeableness affect financial literacy be undertaken. Also, the scope of the study should be expanded to other universities and different academic levels, for instance, the postgraduate level. Further, it would be enlightening to probe the content of curricula to find out how much of their material is designed to improve the financial literacy of students.

\section{References}

Agnew, S., \& Harrison, N. (2015). Financial literacy and student attitudes to debt: A cross-national study examining the influence of gender on personal finance concepts. Journal of Retailing and Consumer Services, 25, 122-129.

Akben-Selcuk, E., \& Altiok-Yilmaz, A. (2014). Financial Literacy Among Turkish College Students: the Role of Formal Education, Learning Approaches, and Parental Teaching 1. Psychological Reports, 115(2), 351-371.

Albeerdy, M. I., \& Gharleghi, B. (2015). Determinants of the Financial Literacy among College Students in Malaysia. International Journal of Business Administration, 6(3), 15-24.

Allen, M. W., Edwards, R., Hayhoe, C. R., \& Leach, L. (2007). Imagined interaction, attitudes towards money and credit, and family coalitions. Journal of Family and Economic Issues, 28, 3-22.

Ansong, A., \& Gyensare, M. A. (2012). Determinants of University Working-Students' Financial Literacy at the University of Cape Coast, Ghana. International Journal of Business and Management, 7(9), 126-134.

Arceo-Gómez, E. O., \& Villagómez, F. A. (2017). Financial literacy among Mexican high school teenagers. International Review of Economics Education, 24, 1-17.

Arellano, A., Camara, N., \& Tuesta, D. (2014). The effect of self-confidence on financial literacy 1428 .

Atkinson, A., \& Messy, F. (2012). Measuring Financial Literacy: Results of the OECD/International Network on Financial Education (INFE) Pilot Study. OECD Working Papers on Finance, Insurance and Private Pensions, 15.

Banks, J., \& Oldfield, Z. (2007). Understanding Pensions: Cognitive Function, Numerical Ability, and Retirement Saving. Fiscal Studies, 28(2), 143-170.

Barnett, M. R. (2015). The politics of cultural nationalism in South India. Princeton University Press. 
Benaboa, R., \& Tirole, J. (2002). Self-Confidence and Personal Motivation. The Quarterly Journal of Economics, 117(3), 871-915.

Benjamin, D. J., Brown, S. A., \& Shapiro, J. M. (2006). Who is 'behavioral'? Cognitive ability and anomalous preferences. Levine's Working Paper Archive.

Blalock, L. L., Tiller, V. R., \& Monroe, P. A. (2004). They Get You Out of Courage: Persistent Deep Poverty among Former Welfare-Reliant Women. Family Relations, 53, 127-137.

Bongini, P., Trivellato, P., \& Zenga, M. (2016). Financial Literacy and Undergraduates. Application of Latent Regression Rasch Model. Journal of Financial Management, Markets and Institutions, 4(1), 23-42.

Borghans, L., Duckworth, A. L., Heckman, J. J., \& Ter Weel, B. (2008). The economics and psychology of personality traits. Journal of Human Resources, 43(4), 972-1059.

Cameron, M. P., Calderwood, R., Cox, A., Lim, S. A., \& Yamaoko, M. (2014). Factors associated with financial literacy among high school students in New Zealand. International Review of Economics Education, 16(PA), 12-21.

Capuano, A., \& Ramsay, I. (2011). What causes suboptimal financial behavior? An exploration of financial literacy, social influences, and behavioral economics. Research Report, Financial Literacy, and Financial Behaviour Financial Literacy Project.

Caspi, A., \& Moffitt, T. E. (2006). Gene-environment interactions in psychiatry: joining forces with neuroscience. Nature Reviews Neuroscience, 7(7), 583-590.

Chen, H., \& Volpe, R. (1998). An analysis of personal financial literacy among college students. Financial Services Review, 7(2), 107-128.

Chen, H., \& Volpe, R. P. (2002). Gender differences in personal financial literacy among college students. Financial Services Review, 11(3), 289-307.

Costa, P. T., Terracciano, A., \& McCrae, R. R. (2001). Gender differences in personality traits across cultures: robust and surprising findings. Journal of personality and Social Psychology, 81(2), 322-331.

Emmons, R. A., Diener, E., \& Larsen, R. J. (1985). Choice of situations and congruence models of interactionism. Personality and Individual Differences, 6, 693-702.

Engelbrecht, L. K. (2011). The Global Financial Crisis: Response of Social Workers to the Financial Capability of Vulnerable Households in South Africa. J. Soc. Intervention: Theory Pract, 20(2), 41-53.

Fonseca, R., Mullen, K. J., Zamarro, G., \& Zissimopoulos, J. (2012). What explains the gender gap in financial literacy? The role of household decision making. Journal of Consumer Affairs, 46(1), 90-106. 


\section{MInstitute Macrothink}

International Journal of Accounting and Financial Reporting ISSN 2162-3082

Gary, B., Sebstad, J., Cohen, M., \& Stack, K. (2009). Can Financial Education Change Behavior? Lessons from Bolivia and Sri Lanka Global Financial Education Program Financial Education Outcomes Assessment. Working Paper \# 4, Microfinance Opportunities, Washington DC.

Glaser, M., \& Walther, T. (2013). Run, Walk, or Buy? Financial Literacy, Dual-Process Theory, and Investment Behavior.

Grable, J. E., \& Joo, S. (1998). Does financial education affect knowledge, attitudes, and behavior? An empirical analysis. Personal Finances and Worker Productivity, 2(2), 213-220.

Greenspan, A. (2003, September 26). Remarks at the 33rd Annual Legislative Conference of the Congressional Black Caucus. Washington, D.C: Federal Reserve.

Hair, J. F., Sarstedt, M., Hopkins, L., \& Kuppelweiser, V. (2014). Partial Least Squares Equation Modeling (PLSSEM): An Emerging Tool for Business Research. European Business Review, 26(2), 106-121.

Hastings, J., Madrian, B., \& Skimmyhorn, W. (2012). Financial Literacy, Financial Education and Economics Outcomes. NBER Working Paper, 18412.

Hough, L. M., \& Oswald, L. (2000). Personnel selection: Looking toward the future--Remembering the past. Annual Review of Psychology, 51, 631-664.

Hung, A., Andrew, P., \& Yoong, J. (2009). Defining and Measuring Financial Literacy. RAND Working Paper, 708.

Johnson, C., \& Staten, M. (2010). Do inter-temporal preferences trump financial education courses in driving borrowing and payment behavior. In 1st Annual Boulder Conference on Consumer Financial Decision Making 3.

Kerkmann, B. C., Lee, T. R., Lown, J. M., \& Allgood, S. M. (2000). Financial management, financial problems, and marital satisfaction among recently married university students. Financial Counseling and Planning,11(2), 55-65.

Lusardi, A., \& Mitchell, O. (2014). The economic importance of financial literacy: theory and evidence. Journal of Economics Literature, 52(1), 5-44.

Lusardi, A., \& Mitchell, O. S. (2013). The economic importance of Financial Literacy: Theory and Evidence. NBER Working Paper Series.

Lusardi, A., Mitchell, O. S., \& Curto, V. (2010). Financial Literacy among the Young. Journal of Consumer Affairs, 44(2), 358-380.

Mandell, L. (2008). Financial literacy of high school students. In Handbook of Consumer Finance Research (pp. 163-183). New York: Springer.

Mandell, L. (2008b). Financial literacy of high school students. In J. Xiao (Ed.), Handbook of Consumer Financial Research. New York: Springer. 


\section{Macrothink}

International Journal of Accounting and Financial Reporting ISSN 2162-3082 2018, Vol. 8, No. 4

Mason, C. L., \& Wilson, R. M. (2000). Conceptualizing Financial Literacy. In Business School Research Series, Paper 2000 UK (p. 7). Loughborough University.

Mbekomize, C., \& Mapharing, M. (2015). Assessment of the Level of Financial Literacy and Economic Behaviour Among College Students in Botswana. International Journal of Economics, Commerce and Management United Kingdom, 3(3).

McCrae, R. R. (1996). Social consequences of experiential openness. Psychological Bulletin, $120,323-337$.

McKenzie, V. M. (2009). The Financial Literacy of University Students: a Comparison of Graduating Seniors Financial Literacy and Debt Level. ProQuest Dissertations and Theses, $33,3-8$.

Miller, M. D., Linn, R. L., \& Gronlund, N. E. (2009). Measurement and Assessment in Teaching (10th ed.). New Jersey: Pearson Education.

Mireku, K. (2015). Financial literacy among University students: evidence from Ghana. Doctoral dissertation, Department of Accounting and Finance, Kwame Nkrumah University of Science and Technology.

Mitchell, O. S., \& Lusardi, A. (2015). Financial Literacy and Economic Outcomes: Evidence and Policy Implications. The Journal of Retirement, 3(1), 107-114.

Mundy, S., \& Masok, C. (2011). Towards an Effective Framework for Financial Literacy and Financial Consumer Protection in Uganda.

Nalini, G. S. (2011). Financial literacy of micro, small and medium entrepreneurs. Int. J. Manage. Res. Rev., 1(5\&9), 89-197.

Norvilitis, J. M., Szablicki, P. B., \& Wilson, S. (2003). Factors influencing levels of credit card debt in college students. Journal of Applied Social Psychology, 33, 935-847.

Oppong-boakye, P. K., \& Kansanba, R. (2013). An Assessment of Financial Literacy Levels among Undergraduate Business Students in Ghana. Research Journal of Finance and Accounting, 4(8), 36-49.

Organization for Economic Co-operation and Development. (2005). Improving Financial Literacy: Analysis of Issues and Policies. OECD.

Palumbo, M. V. (2008). Cognitive ability, job knowledge, and stereotype threat: When does adverse impact result?. Dissertation Abstracts International Section B: The Sciences and Engineering, 68(7-B), 4877.

Patrick, C. (2011). Student evaluations of teaching: effects of the Big Five personality traits, grades, and the validity hypothesis. Assessment and Evaluation in Higher Education. 36(2), 239-249. 


\section{Ml Macrothink}

International Journal of Accounting and Financial Reporting

ISSN 2162-3082 2018, Vol. 8, No. 4

Patrick, C. (2011). Student evaluations of teaching: effects of the Big Five personality traits, grades, and the validity hypothesis. Assessment and Evaluation in Higher Education. 36(2), 239-249.

Peters, E., Västfjäll, D., Slovic, P., \& Mertz, C. (2006). Numeracy and decision making. Psychological Science, 17(5), 407.

Refera, M. K., Dhaliwal, N. K., \& Kuar, J. (2016). Financial Literacy for Developing countries in Africa: A review of concepts, significance and research opportunities. Journal of African Studies and Development, 8(1), 1-12.

Shaari, N. A., Hasan, N. A., Ramesh Kumar Moona Haji, M., \& Mior Ahmad Jafri Md, S. (2013). Financial Literacy: a Study Among the University Students. Interdisciplinary Journal of Contemporary Research in Business, 5(2), 279.

Shankari, S., Navarathinam, K., \& Suganya, R. (2014). Financial Literacy towards Banking Products and Services: A survey. Int. J. Manage. Res. Rev., 4(3), 396-402.

Watson, D., \& Clark, L. (1997). Extraversion and its positive emotional core. In R. Hogan, J. Johnson, \& S. Briggs (Eds.), Handbook of Personality Psychology (pp. 767-793).

\section{Copyright Disclaimer}

Copyright for this article is retained by the author(s), with first publication rights granted to the journal.

This is an open-access article distributed under the terms and conditions of the Creative Commons Attribution license (http://creativecommons.org/licenses/by/4.0/) 